\title{
Inequalities in mortality by socioeconomic factors and Roma ethnicity in the two biggest cities in Slovakia: a multilevel analysis
}

Katarina Rosicova ${ }^{1,2,3^{*}}$, Sijmen A. Reijneveld ${ }^{4}$, Andrea Madarasova Geckova ${ }^{2,3,5}$, Roy E. Stewart ${ }^{4}$, Martin Rosic ${ }^{6}$, Johan W. Groothoff ${ }^{4}$ and Jitse P. van Dijk $2,4,5$

\begin{abstract}
Background: The socioeconomic and ethnic composition of urban neighbourhoods may affect mortality, but evidence on Central European cities is lacking. The aim of this study was to assess the associations between socioeconomic and ethnic neighbourhood indicators and the mortality of individuals aged 20-64 years old in the two biggest cities of the Slovak Republic.
\end{abstract}

Methods: We obtained data on the characteristics of neighbourhoods and districts (educational level, unemployment, income and share of Roma) and on individual mortality of residents aged 20-64 years old, for the two largest cities in the Slovak Republic (Bratislava and Kosice) in the period 2003-2005. We performed multilevel Poisson regression analyses adjusted for age and gender on the individual (mortality), neighbourhood (education level and share of Roma in population) and district levels (unemployment and income).

Results: The proportions of Roma and of low-educated residents were associated with mortality at the neighbourhood level in both cities. Mutually adjusted, only the association with the proportion of Roma remained in the model (risk ratio 1.02; $95 \%$ confidence interval 1.01-1.04). The area indicators - high education, income and unemployment - were not associated with mortality.

Conclusion: The proportion of Roma is associated with early mortality in the two biggest cities in the Slovak Republic.

Keywords: Mortality, Multilevel analyses, Roma population, Socioeconomic indicators, Urban areas

\section{Background}

Inequalities in health between socioeconomic and ethnic groups are among the main challenges for public health worldwide and have been an object of study in recent decades $[1,2]$. These inequalities exist at many levels between individuals, neighbourhoods, socioeconomic groups, regions, countries and entire continents. Attempts to reduce social inequalities in health often focus on geographical disparities, since policy is most easily directed at administrative units such as local governments [3].

\footnotetext{
* Correspondence: Katarina.Rosicova@vucke.sk

${ }^{1}$ Kosice Self-governing Region, Department of Regional Development,

Land-use Planning and Environment, Nam. Maratonu mieru 1, 04266 Kosice,

Slovakia

${ }^{2}$ Graduate School Kosice Institute for Society and Health, Safarik University,

Kosice, Slovakia

Full list of author information is available at the end of the article
}

The number of studies treating geographical area as a separate level when studying health determinants has increased in the last two decades [3-24]. However, area inequalities in mortality within cities have been analysed much less frequently in European contexts [25-28]. This holds more for Central Europe, even though socioeconomic inequalities in health may be larger in urban areas with disadvantaged and poor populations, affecting, as a result, all city residents. Disease outbreaks, poorly maintained public places, social unrest, crime and violence are but a few of the ways that urban health inequities affect everyone. These peculiar characteristics of cities probably contribute to inequalities in health [29].

(C) 2015 Rosicova et al. Open Access This article is distributed under the terms of the Creative Commons Attribution 4.0 International License (http://creativecommons.org/licenses/by/4.0/), which permits unrestricted use, distribution, and reproduction in any medium, provided you give appropriate credit to the original author(s) and the source, provide a link to the Creative Commons license, and indicate if changes were made. The Creative Commons Public Domain Dedication waiver (http://creativecommons.org/publicdomain/zero/1.0/) applies to the data made available in this article, unless otherwise stated. 
Regarding socioeconomic indicators, most multilevel studies have focused on the association between mortality and the income or education level of the population within an area $[4-12,15,18,24,30-34]$. Furthermore, they mostly concern Western European countries $[6,7,9-12,15,17,18]$, the United States $[5,24]$, Japan or Australia [19, 22, 23] and only recently Central Europe $[35,36]$. These studies generally indicate that the income of a population within an area is a strong socioeconomic indicator of regional mortality, and that regional mortality is significantly higher in regions with larger income disparities $[5,10,11,24]$ or with lower socioeconomic status [1, 2, 23, 26, 37, 38]. Moreover, the effects of income inequality are most evident for those aged 25-64 and much stronger for males [5]. Finally, these studies have shown that the education level of the population within an area strongly correlates with the local mortality rates: people with a high education (including both sexes) have lower mortality compared with the least educated $[9,12,31,33,34]$. A clear picture on urban health inequalities in Central Europe is for the most part lacking.

Roma represent a large minority in the Slovak population, and they are characterised by an extremely high degree of territorial segregation, poverty and perceived discrimination $[39,40]$. The health of the adult Roma population in the Slovak Republic is worse than that of the majority population. This may be due to their poor socioeconomic situation (low educational level, high unemployment rate, high proportion of poverty) and the related unsuitable living conditions and infrastructure in their places of abode, especially in the so-called settlements [39-41].

The aim of this study was to analyse the mortality of an urban population and to explore the association between area indicators - socioeconomic and ethnicity factors of the population within an area - and the mortality of individuals aged 20-64 years old on the neighbourhood level in the two biggest cities of the Slovak Republic, as an example of a Central European country.

\section{Methods}

\section{Study population}

The study population concerned inhabitants aged 20-64 years old in the two largest cities in the Slovak Republic Bratislava and Kosice - in the period 2003 - 2005. The analyses were restricted to those aged 20-64 years old in order to cover the economically active population. This part of the population has the relatively lowest mortality rate, has finished the process of education and typically receives some kind of income, either in the form of a salary or as social support benefits.

In the study period the average number of inhabitants aged 20-64 years old in Bratislava and Kosice was 442,703 (47.4 \% men). The total number of deaths among those aged 20-64 years old over the 3 years was 5092 (66.1\% men), i.e., a mean of 1697 per year (see also Table 1 ).

\section{Measures}

The data in this study represent three hierarchical levels: the individual, the neighbourhood and the district levels, the latter two concerning the areas where the individuals live. Individual-level data concerned the numbers of residents and the numbers of deaths, by gender and age, per neighbourhood and district of Bratislava and Kosice. Data were obtained from the Statistical Office of the Slovak Republic.

To be able to assess differences in mortality by area characteristics, we obtained data at the neighbourhood and district levels. Bratislava and Kosice are hierarchically divided into districts, which are further subdivided into neighbourhoods. Bratislava, the capital city, comprises 5 districts and 17 neighbourhoods, and Kosice, the second largest city, 4 districts and 22 neighbourhoods. The mean number of inhabitants aged 20-64 per district was 49,189 persons, ranging from 22,775 to 89,477 (average for the period 2003 - 2005). Per neighbourhood the mean number was 11,351 inhabitants, ranging from 205 to 86,722 (average for the period 2003-2005).

Table 1 Basic data for the Slovak population and the cities of Bratislava and Kosice for persons aged 20-64 years old - averages for the period $2003-2005$

\begin{tabular}{|c|c|c|c|c|c|c|}
\hline & \multicolumn{2}{|c|}{ Slovak Republic } & \multicolumn{2}{|c|}{ Bratislava } & \multicolumn{2}{|l|}{ Kosice } \\
\hline & Males & $\overline{\text { Females }}$ & Males & $\overline{\text { Females }}$ & Males & $\overline{\text { Females }}$ \\
\hline Standardised mortality (per 100,000 inhabitants) & 616.1 & 242.2 & 485.7 & 225.5 & 563.1 & 252.4 \\
\hline Low education (elementary and without elementary) ${ }^{a}$ & $12.2 \%$ & $19.5 \%$ & $6.3 \%$ & $8.6 \%$ & $6.8 \%$ & $11.9 \%$ \\
\hline High education (tertiary) ${ }^{\mathrm{a}}$ & $12.6 \%$ & $11.2 \%$ & $31.0 \%$ & $27.5 \%$ & $21.3 \%$ & $17.5 \%$ \\
\hline Unemployment rate & $11.2 \%$ & $10.3 \%$ & $2.3 \%$ & $2.6 \%$ & $8.8 \%$ & $8.5 \%$ \\
\hline Income (whole population) & $€ 491$ & $€ 356$ & $€ 705$ & $€ 501$ & $€ 521$ & $€ 380$ \\
\hline Roma $^{a}$ & $1.4 \%$ & $1.3 \%$ & $0.1 \%$ & $0.1 \%$ & $1.6 \%$ & $1.4 \%$ \\
\hline
\end{tabular}

Source: Data from the Statistical Office of the Slovak Republic

aPopulation census, 2001 
We obtained data on several neighbourhood characteristics: education level, unemployment rate, income and the proportion of Roma in the population of the neighbourhoods or districts. If these data were not available on the neighbourhood level (unemployment rate, income), we used data regarding the district level. The education level of the population within an area concerned two percentages regarding inhabitants aged 20-64 years old per area: those having no elementary education or only elementary education, and those having tertiary education. These data were based on the 2001 population census of the Statistical Office of the Slovak Republic [42]. The unemployment rate of the population within an area concerned the proportion of unemployed inhabitants (people not paid by an employer at all) per area aged 20-64 years old in the period 2003 - 2005 [43]. Data were obtained from the tally of the Centre of Labour, Social Affairs and Family of the Slovak Republic. The income of the population within an area concerned the average monthly wage of employees per area and was obtained from the Statistical Office of the Slovak Republic. Income data are available only at the district level and in the form of gross income (net income is about $75 \%$ of gross income) and only for companies with 20 and more employees (about $60 \%$ of all companies in the country) [44]. The proportion of Roma within an area concerned the percentage of the population aged 20-64 years old with Roma ethnicity per area and was obtained from the 2001 population census of the Statistical Office of the Slovak Republic [45].

\section{Mortality}

Data on mortality concerned the number of deaths per neighbourhood during 2003 - 2005 combined, divided into 5-year age categories (20-24, 25-29, etc.) and by gender.

\section{Statistical analysis}

We first computed standardised mortality rates per neighbourhood, standardising by age to the total population of Slovakia. Next, we performed Poisson regression analyses in which we used mortality as the outcome and the number of inhabitants per age and gender category as the predictors. We then added the following neighbourhood characteristics to this model: education level, unemployment, income and share of Roma. We first did this for each neighbourhood characteristic separately, and we then introduced them all at once. Because of the hierarchical nature of the data - the characteristic of an area affecting all residents - we used multilevel techniques; i.e., we applied three-level Poisson regression analyses, with the levels being the individual $i$, the neighbourhood $j$ and the district $k$. In these models we allowed an extra Poisson variation to estimate the level-1 (individual level) variance [46]. These analyses yielded crude and adjusted mortality risks for the various area characteristics. To assess the degree of clustering by area, we also computed random variances at the area level as well as intra class correlations (ICC).

Multilevel models provide an appropriate statistical method for describing and explaining geographic health inequalities on a range of spatial scales [21]; in other words, they allow researchers to identify 'place effects' on health over and above individual characteristics. The adverse health effects of area deprivation, over and above the effect due to individual SES, can only be analysed properly if the hierarchical nature of the effects is accounted for [16], i.e., characteristics of areas and communities have a potential impact on all residents [16]. Random variables at both levels were modelled to take this into account. The use of random variables at two (or more) levels of aggregation is specific for multilevel models [16].

The probability of death $\pi$ of the $\mathrm{i}$-th individual in the $\mathrm{j}$-th neighbourhood in the $\mathrm{k}$-th district was modelled as follows:

$$
\begin{aligned}
\log \left(\pi_{\mathrm{ijk}}\right)= & \log \left(\mathrm{E}_{\mathrm{ijk}}\right)+\text { constant }_{0 \mathrm{jk}}+\beta_{1} \mathrm{x}_{1 \mathrm{ijk}} \\
& +\beta_{2} \mathrm{x}_{2 \mathrm{ijk}}+\ldots+\gamma_{1} \mathrm{z}_{1 \mathrm{ik}}+\gamma_{2} \mathrm{z}_{2 \mathrm{ik}}+\ldots \\
& +\left(\mathrm{e}_{\mathrm{jk}}+\mathrm{e}_{\mathrm{k}}\right)
\end{aligned}
$$

where

$\log \left(\pi_{\mathrm{ijk}}\right)$ follows a Poisson-distribution with mean $\pi$ (and thus also variance $\pi$ )

$\log \left(\mathrm{E}_{\mathrm{ijk}}\right)$ is the offset of the Poisson model (i.e., the $\log$ of the expected death count for ijk)

$\beta_{1}$ represents the regression coefficient for $x_{1}$ for the individuals in the $\mathrm{j}$-th neighbourhood in the $\mathrm{k}$-th district $\mathrm{k}$ ( $\beta_{2}$ for $x_{2}$, etc.)

$\gamma_{1}$ represents the regression coefficient for $z_{1}$ for the individuals in the $\mathrm{k}$-th district $\left(\gamma_{2}\right.$ for $z_{2}$, etc.)

$\mathrm{e}_{j \mathrm{k}}$ and $\mathrm{e}_{\mathrm{k}}$ are random terms following a normal

distribution, for neighbourhoods (level ${ }_{j}$ ) and districts $\left(\right.$ level $\left._{\mathrm{k}}\right)$, respectively.

Analyses were done using SAS version 9.1., MlWin version 2.22, and SPSS version 17.0.

\section{Results}

\section{Mortality}

In the period 2003 - 2005 the standardised mortality rates for the total population aged 20-64 years old in the Slovak Republic were 616.1 deaths per 100,000 inhabitants per year for males and 242.2 deaths per 100,000 inhabitants per year for females (Figs. 1 and 2). Regarding males, these death figures were 485.7 for Bratislava (range: 202.5 to 1665.2) and 563.1 for Kosice (range: 204.1 to 1629.8). Compared with the standardised mortality rate for males aged 20-64 years old at the national level, 10 neighbourhoods in Bratislava and Kosice (25 \%) had a higher 


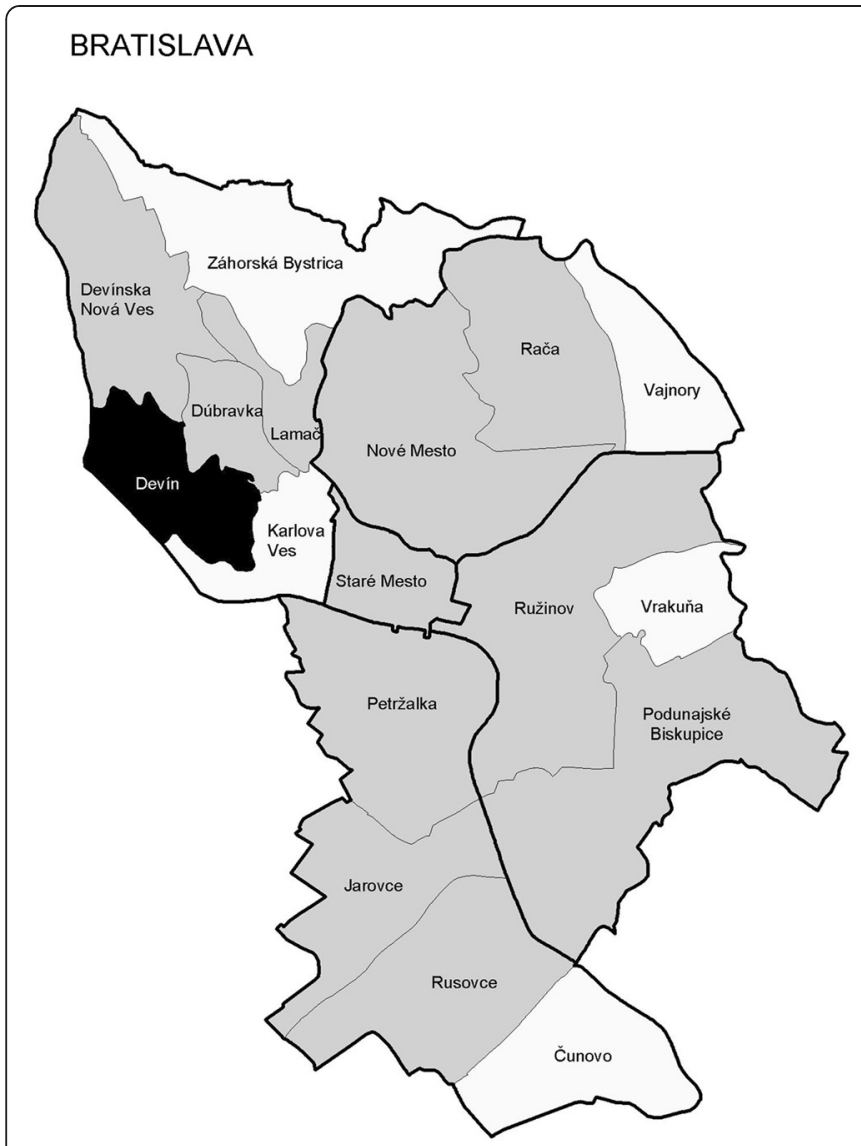

KOŠICE

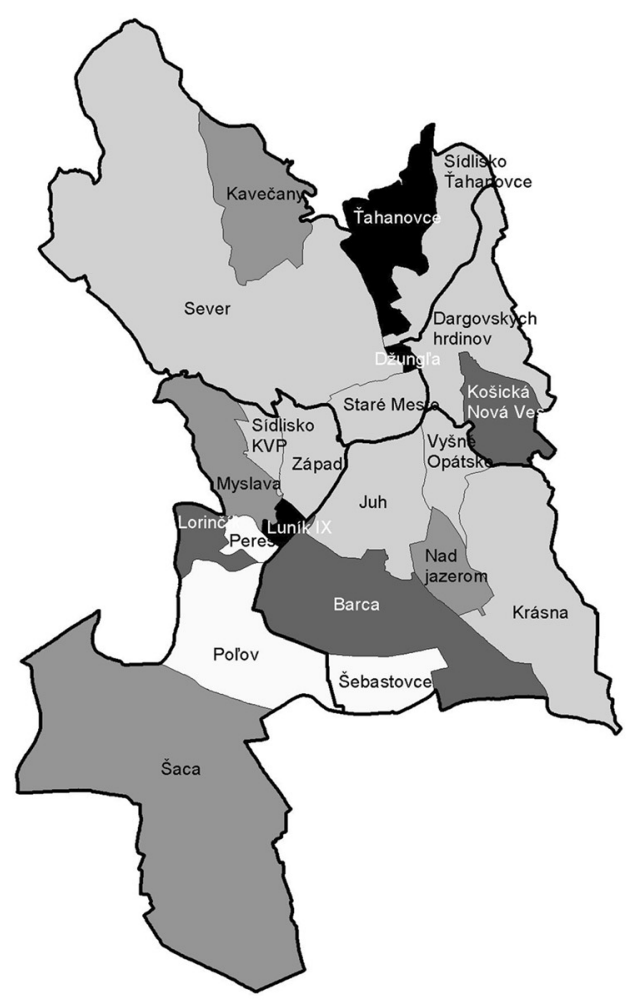

Averages of standardised mortality rates per year for males:

* Bratislava $=485.7$ per 100,000 inh.

${ }^{*}$ Kosice $=563.1$ per 100,000 inh.

* Slovak Republic $=616.1$ per 100,000 inh.

Standardised by age structure of the Slovak population

Fig. 1 Standardised mortality rates for males aged 20-64 years by district and neighbourhood in Bratislava and Kosice. Source: Data from the Statistical Office of the Slovak Republic

standardised mortality rate than the average rate for the Slovak Republic; 9 of these were in Kosice (Fig. 1).

Regarding females, the average standardised mortality rates were 225.5 per 100,000 for Bratislava (range: 163.9 to 587.9) and 252.4 for Kosice (range: 0.0 to 1314.3). The mortality rate for females in the examined neighbourhoods showed less marked disparities. Half of the neighbourhoods (20 out of 39 ) attained a higher standardised mortality rate for females aged 20-64 years old than the average national mortality rate, this being 242.2 deaths per 100,000 inhabitants per year in the study period; 14 of these were in Kosice (Fig. 2).

Association of neighbourhood characteristics with mortality Using multilevel Poisson regression we assessed the associations of the various area characteristics with age- and gender-adjusted mortality. In the initial crude model the degree of clustering, measured by random variance at the neighbourhood level, was statistically significant. No additional clustering occurred at the district level; therefore, this level was omitted from further analyses. Mortality risks were highest for the neighbourhood characteristics proportion of the population with low education and the proportion of Roma in the population. Introduction of the various neighbourhood characteristics led to a decrease in the random variance at the area level, i.e., a lower ICC, showing that these characteristics accounted for part of the clustering.

In the second step, we assessed the mortality risks for the two variables that led to the largest decrease in clustering for their mutual effects, mutually adjusted. This showed that only the association of mortality with the 


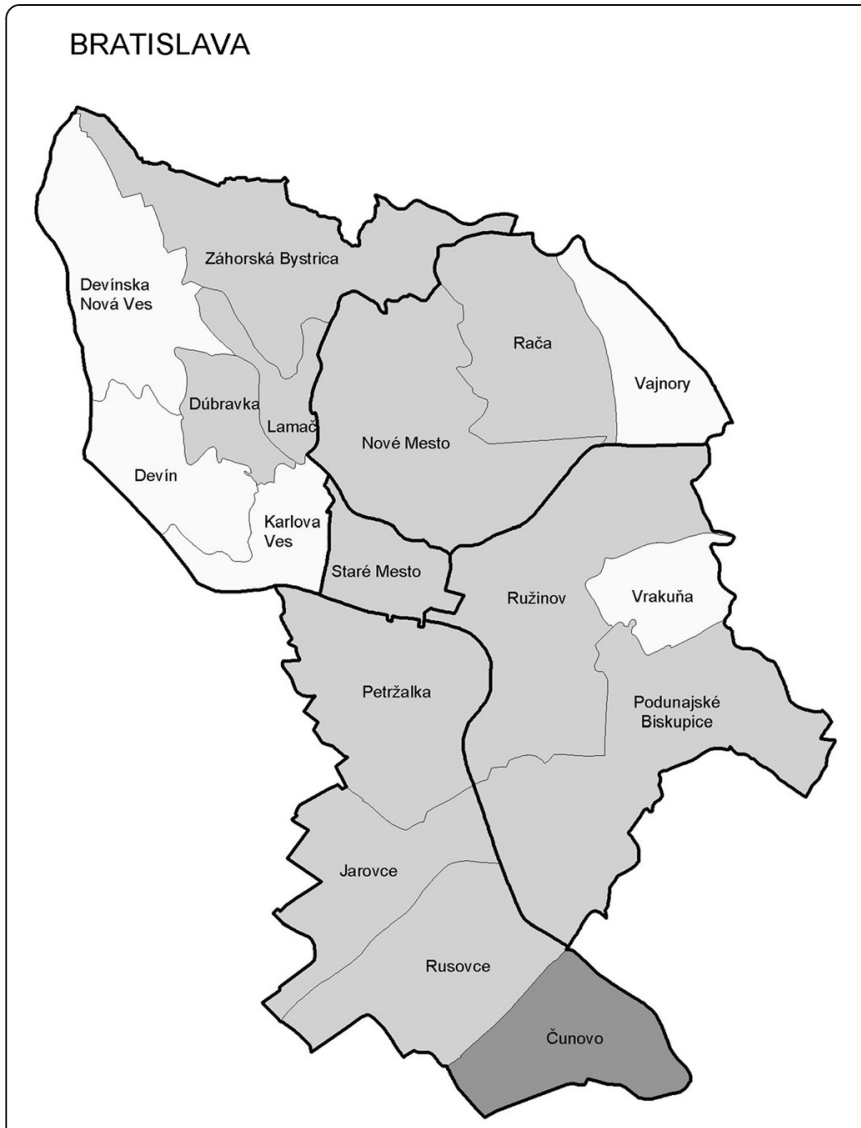

KOŠıCE

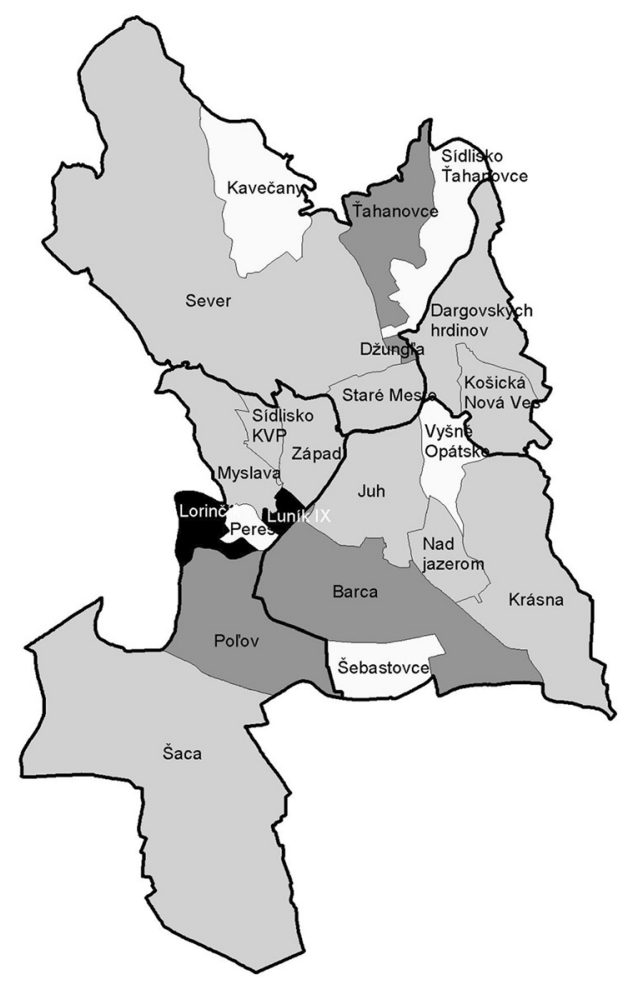

Averages of standardised mortality rates per year for females:

* Bratislava $=225.5$ per 100,000 inh.

${ }^{*}$ Kosice $=252.4$ per 100,000 inh.

* Slovak Republic $=242.2$ per 100,000 inh.

Standardised by age structure of the Slovak population

Fig. 2 Standardised mortality rates for females aged 20-64 years by district and neighbourhood in Bratislava and Kosice. Source: Data from the Statistical Office of the Slovak Republic

proportion of Roma within an area remained statistically significant. We did not adjust for the other characteristics because of their apparent collinearity. In this adjusted analysis, the intra-class correlation further decreased, to 0.022 (Table 2).

Figure 3 shows the spatial distribution of the Roma population (declared Roma ethnicity) by districts and neighbourhoods in Bratislava and Kosice from census data. For these two cities, the population with Roma ethnicity aged 20-64 years old is concentrated mainly in Kosice, in particular in three neighbourhoods. In the other neighbourhoods of both cities the Roma population lives largely integrated within the majority population and did not list their ethnicity as Roma in the census.

\section{Discussion}

The aim of our study was to explore the association between socioeconomic and ethnic indicators of urban areas and the mortality of individuals aged 20-64 years old in the two biggest cities of the Slovak Republic. Our findings indicate that the proportions of Roma within an area and of those with low education per area are associated with the mortality of the urban population aged 20-64 years old. The mutually adjusted model showed that only the proportion of Roma within an area predicted the standardised mortality rate.

We found differences in mortality and in all socioeconomic indicators (education level, unemployment rate, income) and ethnicity (Roma population) between Bratislava and Kosice. These differences are based mainly on macro- 
Table 2 Associations of neighbourhood characteristics with age- and gender-adjusted mortality, bivariate and with mutual adjustment: rate ratios (RR), $95 \%$ confidence intervals (Cl) and intraclass correlation coefficients (ICC)

\begin{tabular}{|c|c|c|c|c|c|c|}
\hline & \multicolumn{3}{|c|}{ Unadjusted mortality risk $^{\mathrm{a}}$} & \multicolumn{3}{|c|}{ Adjusted mortality risk ${ }^{\mathrm{b}}$} \\
\hline & RR & $(95 \%-\mathrm{Cl})$ & ICC & $\overline{\mathrm{RR}}$ & $(95 \%-\mathrm{Cl})$ & ICC \\
\hline High Education & 0.992 & $0.986-0.9989$ & 0.048 & & & 0.022 \\
\hline Low Education & 1.010 & $1.004-1.016$ & 0.032 & 1.004 & $0.998-1.010$ & \\
\hline Income (in Euro's) & 0.999 & $0.999-1.000$ & 0.025 & & & \\
\hline Unemployment & 1.011 & $0.993-1.029$ & 0.025 & & & \\
\hline Roma & 1.028 & $1.016-1.041$ & 0.032 & 1.023 & $1.009-1.037$ & \\
\hline
\end{tabular}

Source: Data from the Statistical Office of the Slovak Republic

ay neighbourhood characteristic, adjusted for age and gender

${ }^{b}$ Additionally adjusted for the other area characteristic mentioned

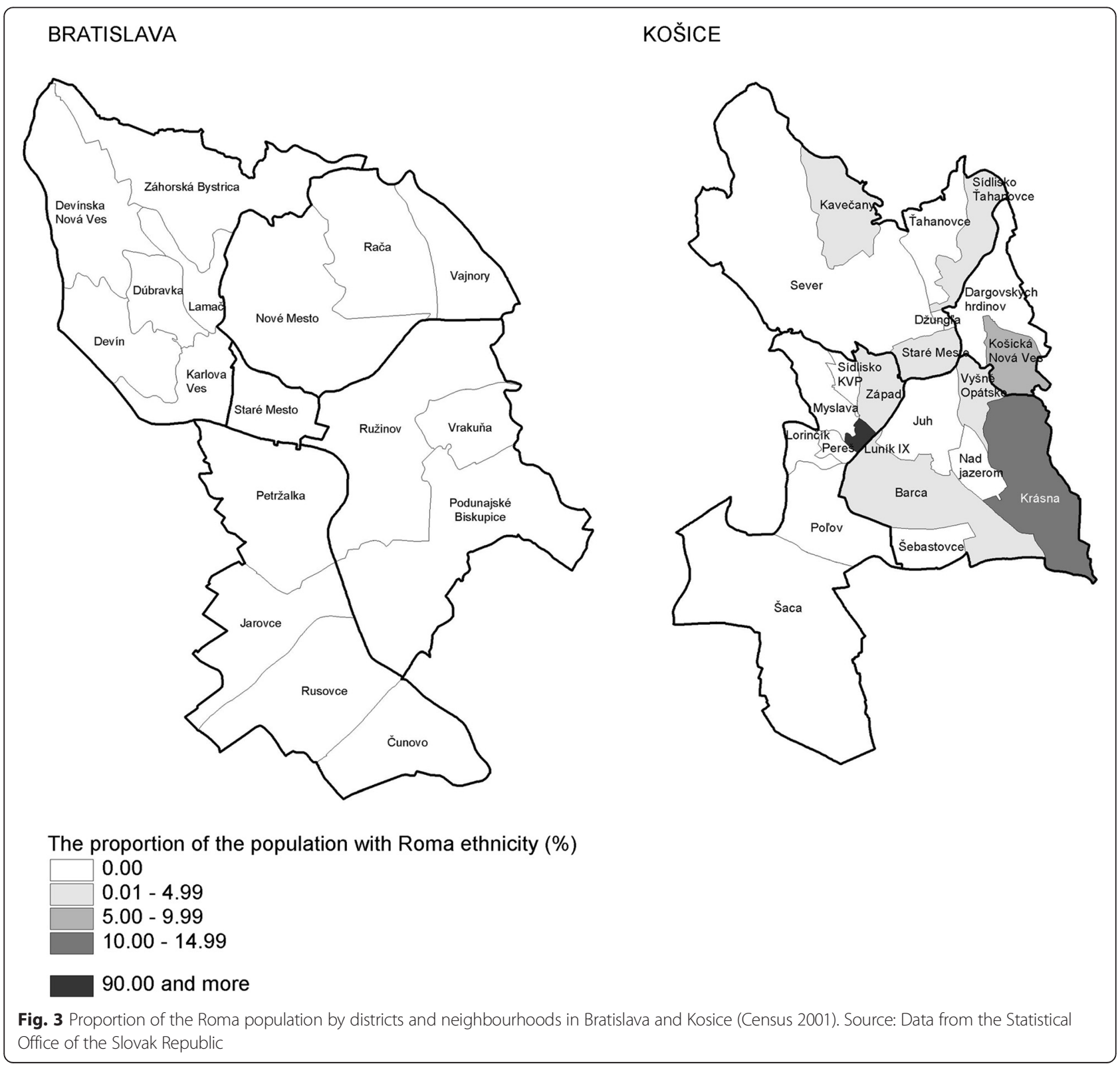


spatial attractiveness (the west-east gradient), where Bratislava has a specific position due to the strong Central Europe Vienna - Budapest economic region and polarisation of the extremely developed Bratislava region (the capital city) on one hand and the rest of the Slovak Republic on the other [47]. The significant determinants of the characteristics of the Roma population are regional factors and factors regarding integration. Roma live across the whole territory of the Slovak Republic; nevertheless, there are large differences in their numbers, concentration and reproductive behaviour in different regions (48). The regions with the highest proportion of the Roma population are located in the southern part of Central Slovakia and in East Slovakia (including Kosice city) and correspond with the regions having an unfavourable socioeconomic structure [47]. The Roma population is disadvantaged by lower education levels and greater illiteracy, which represent a major barrier to successful involvement in the labour market [41].

At the neighbourhood level of Bratislava and Kosice the proportion of Roma in the population contributed to the difference in the standardised mortality rate, but in general this contribution is modest, due to a few neighbourhoods with high mortality rates and high shares of Roma. In Kosice the variation in mortality rates was generally larger and the share of Roma was higher than in Bratislava. In comparison with other studies $[49,50]$, our findings show a lower level of social "ghettoised" suburban areas in these two Slovak cities, which still have a relatively homogeneous distribution of SES across areas $[35,36]$. This finding contrasts with previous findings on the regional disparities of mortality in the Slovak Republic $[30,51,52]$. Those studies showed the proportion of Roma, as an indicator of area deprivation, to be significantly associated only with infant mortality and not with adult mortality, which was significantly associated with education level or unemployment. Only a modest association between ethnicity and area mortality differences was found in the Netherlands [16], and moreover, it was found that non-Western residents seem to benefit from living in an urban environment [53].

Several studies have shown that Roma, regardless of the region they live in, have poorer health, lower life expectancy and a higher prevalence of many diseases compared with national averages or with majority populations [41, 54-57]. There are also studies that show the contribution of socioeconomic characteristics in the explanation of health differences between Roma and non-Roma [58-60]. According to the UNDP report on the living conditions of the Roma population in the Slovak Republic [41], the health of the Roma population in Slovakia is related to their poor living conditions and the poor infrastructure in their places of living, especially in settlements. In addition, Roma also have on average a very low education level, which may also contribute to their higher mortality [41, 60, 61].

\section{Strengths and limitations of the study}

The strengths of our study are its small area design, the combination of area and individual data, the availability of age-specific population data and the perspective over time. In many countries individual-based data on mortality by age are not available, whereas area-based data are mostly available and comparable. Multilevel analysis provides a way to link traditionally distinct ecologicaland individual-level studies and to overcome the limitations inherent in focusing only on one level.

The limitations of the present study are the lack of neighbourhood data on income and a potential underestimation of the number of Roma. The indicator of income (average monthly gross payment) is available at the district level in Slovakia only for companies with 20 or more employees. The share of such enterprises in the total labour market is about $60 \%$. As for the data on the population with Roma ethnicity, we used data from the national population census, which is based on self-identification [62]. These official censuses may underestimate the real numbers of Roma due to the tendency of Roma to denote themselves as members of more positively assessed ethnic groups [60]. A simple count of the Roma population may yield better estimates for Roma living in settlements but is not feasible for those not living in settlements. As Roma settlements occur only in Kosice and not in Bratislava, this would lead to biased regional comparisons. Therefore, we used census data because they are less biased.

\section{Implications}

Our findings are new and thus require confirmation for other Central European countries to assess whether they are country-specific or whether they fit into a pattern which extends over several countries. Moreover, urban mortality should be analysed in relation to other health and socioeconomic factors (like social class, regional GDP and the regional Gini-index), as well as trends that occur over time.

Our results show a need to address the health needs of deprived urban areas in the Slovak Republic. These needs may be met by approaches as described by the commissioner on socioeconomic health differences [63], which are also usable in the conditions of the two largest cities in Slovakia. Improving daily living conditions is mainly a task of local government and civil society, backed by the national government, to establish local participatory governance mechanisms that enable communities and local governments to partner in building healthier and safer cities. Furthermore, local governments and civil society should manage urban development to ensure greater availability of affordable quality housing. Finally, they should 
plan and design urban areas to promote physical activity through investment in active transport; encourage healthy eating through retail planning to manage the availability of and access to food; and reduce violence and crime. Measuring and understanding the problem and assessing the impact of actions are mainly the tasks of research institutions and the relevant ministries. They can also help to make the social determinants of health a standard and compulsory part of training for medical and health professionals [62].

In addition, it is also important to consider interventions aimed at a revitalisation of all areas facing structural difficulties, such as e.g., proposed by EU Structural Funds. Within the framework of a policy of redistributing parts of government over the country, interventions aiming to revitalise deprived areas should focus on creating employment in such areas, e.g., by improving the developed environment, social structures (small work projects, social care, safety).

In the Slovak Republic several policies and strategies exist that focus on health, mortality, reducing regional differences and on the studied variables, including at the local level. Elaboration of these policies is an issue mentioned in the Law on regional development of the Slovak Republic, and the cities of Bratislava and Kosice have each developed such policies. Policies aimed at reducing disparities in different areas and evaluating key determinants of health can be expected to have a positive impact on the health of the population. Implementation of these policies and the application of such laws in practice is a very important step.

Regarding the Roma issue, a 'Strategy of the Slovak Republic regarding the integration of Roma communities up to 2020 ' already exists. The goal of this 'Strategy' is to counteract social exclusion, which occurs through the economic, cultural, symbolic and spatial exclusion of Roma communities in comparison with the non-Roma population. This policy is new; thus its impact on health will be noticeable only by thorough implementation and careful assessment of its effectiveness and by setting realistic and measurable indicators and their subsequent strict monitoring and evaluation. As Roma issues are rather complicated problems, no easy solutions are available. In the long term - a small steps approach is needed, and even then it is questionable if a not significant difference in life expectancy between Roma and non-Roma will ever be reached.

\section{Conclusion}

The proportion of Roma was the strongest area-level predictor of urban mortality in the two biggest cities in Slovakia. A question to be answered is which concept is behind it, as other area indicators such as the proportion of inhabitants with a high education, the average monthly gross income and the unemployment rate of an area did not contribute to the prediction of mortality. Developing and implementing policies on the national, regional and local level aimed at reducing socioeconomic inequalities in mortality and addressing the health needs of the most deprived groups and the most deprived areas seems to be important for the further economic development of the country. Further research is needed to unravel the causal pathway between this particular area level predictor and socioeconomic inequalities in mortality.

\section{Competing interests}

The authors declare that they have no competing interests.

\section{Authors' contributions}

KR drafted the manuscript, analysed the statistical data and prepared outputs of the analysis. SAR participated in the design of the study, performed the statistical analysis and participated in its design and coordination and helped to draft the manuscript. AMG participated and helped to draft the manuscript. RES carried out the statistical analysis. MR participated in the design of the study from side of socioeconomic indicators. JWG participated in the design of the study. JPVD conceived the study, and participated in its design and coordination and helped to draft the manuscript. All authors read and approved the final manuscript.

\section{Acknowledgement}

This work was supported by 1) the Research and Development Support Agency under Contract No. APW-00-032-11, 2) VEGA 1/0346/12, 3) partially supported by the Agency of the Slovak Ministry of Education for the Structural Funds of the EU under project ITMS: 26220120058 (40 \%), 4) partially funded within the framework of the project "Social determinants of health in socially and physically disadvantaged and other groups of population" (CZ.1.07/2.3.00/20.0063) and 5) finally, by the INEQ-CITIES Project - Socioeconomic inequalities in mortality: evidence and policies in cities of Europe; grant agreement number 200812 13, proposal number: 101156, acronym: INEQ-CITIES.

\section{Author details}

${ }^{1}$ Kosice Self-governing Region, Department of Regional Development, Land-use Planning and Environment, Nam. Maratonu mieru 1, 04266 Kosice, Slovakia. ${ }^{2}$ Graduate School Kosice Institute for Society and Health, Safarik University, Kosice, Slovakia. ${ }^{3}$ Institute of Public Health - Department of Health Psychology, Medical Faculty, Safarik University, Kosice, Slovakia. ${ }^{4}$ Department of Community and Occupational Health, University Medical Center Groningen, University of Groningen, Groningen, The Netherlands. ${ }^{5}$ Olomouc University Society and Health Institute, Palacky University Olomouc, Olomouc, Czech Republic. ${ }^{6}$ Faculty of Humanities and Natural Sciences, University of Presov, Presov, Slovakia.

Received: 20 May 2015 Accepted: 1 November 2015

Published online: 05 November 2015

\section{References}

1. Mackenbach JP, Stirbu I, Roskam AJR, Schaap MM, Menvielle G, Leinsalu M, et al. Socioeconomic inequalities in health in 22 European countries. N Engl J Med. 2008;358:2468-81.

2. Marmot M. Social determinants of health inequalities. Lancet. 2005;356:1099-104.

3. Macintyre S, Maciver S, Sooman A. Area, class and health: should we be focusing on place or people? J Soc Policy. 1993;22:213-34.

4. Adams RJ, Howard N, Tucker G, Appleton S, Taylor AW, Chittleborough C, et al. Effect of area deprivation on health risks and outcomes: a multilevel, crosssectional, Australian population study. Int J Public Health. 2009;54:183-92.

5. Backlund E, Rowe G, Lynch J, Wolfson MC, Kaplan GA, Sorlie PD. Income inequality and mortality: a multilevel prospective study of 521248 individuals in 50 US states. Int J Epidemiol. 2007;36:590-6.

6. Blomgren J, Martikainen P, Makela P, Valkonen T. The effects of regional characteristics on alcohol-related mortality - a register-based multilevel analysis of 1.1 milion men. Soc Sci Med. 2004;58:2523-35. 
7. Breckenkamp J, Mielck A, Razum O. Health inequalities in Germany: do regional-level variables explain differentials in cardiovascular risk? BMC Public Health. 2007;7:132

8. Cavalini LT, Ponce de Leon ACM. Morbidity and mortality in Brazilian municipalities: a multilevel study of the association between socioeconomic and healthcare indicators. Int J Epidemiol. 2008;37:775-85.

9. Dalmau-Bueno A, Garcia-Altes A, Mari-Dell'olmo M, Perez K, Espelt A, Kunst $A E$, et al. Trends in socioeconomic inequalities in cirrhosis mortality in an urban area of Southern Europe: a multilevel approach. J Epidemiol Community Health. 2010;64:720-7.

10. Elstad Jl. Does the socioeconomic context explain both mortality and income inequality? Prospective register-based study of Norwegian regions. Int J Equity Health. 2011;10:7.

11. Henriksson G, Allebeck P, Weitoft GR, Thelle D. Income distribution and mortality: Implications from a comparison of individual-level analysis and multilevel analysis with Swedish data. Scand J Public Health. 2006;34:287-94.

12. Kravdal O. Mortality effects of average education: a multilevel study of small neighbourhoods in rural and urban areas in Norway. Int J Equity Health. 2009;8:41.

13. Macintyre S, Ellaway A, Cummins S. Place effects on health: how can we conceptualise, operationalise and measure them? Soc Sci Med. 2002;55:125-39.

14. Marmot M, Commission on Social Determinants of Health. Achieving health equity: from root causes to fair outcomes. Lancet. 2007;370:1153-63.

15. Pinzone F, Casuccio N, Cusimano R, Mancuso A, Pitarresi A. Mortality in relation to individual- and area-level socioeconomic status in Palermo (Italy): a multilevel analysis. Epidemiol Prev. 2009;33:207-14.

16. Reijneveld SA, Verheij RA, de Bakker DH. Relative importance of urbanicity, ethnicity and socioeconomic factors regarding area mortality differences. J Epidemiol Community Health. 1999;53:444-5.

17. Reijneveld SA, Veenstra R, de Winter AF, Verhulst FC, Ormel J, de Meer G. Area deprivation affects behavioral problems of young adolescents in mixed urban and rural areas: the TRAILS study. J Adolescent Health. 2010;46:189-96.

18. Šlachtová H, Tomášková H, Šplíchalová A, Polaufová P, Fejtková P. Czech socio-economic deprivation index and its correlation with mortality data. Int J Public Health. 2009:54:1-7.

19. Bentley R, Kavanagh AM, Subramanian SV, Turrell G. Area disadvantage, individual socio-economic position, and premature cancer mortality in Australia 1998 to 2000: a multilevel analysis. Cancer Causes Control. 2008;19:183-93.

20. Jackson AL, Davies CA, Leyland AH. Do differences in the administrative structure of populations confound comparisons of geographic health inequalities? BMC Med Res Methodol. 2010;10:74

21. Meijer M, Rohl J, Bloomfield K, Grittner U. Do neighborhoods affect individual mortality? A systematic review and meta-analysis of multilevel studies. Soc Sci Med. 2012;74:1204-12.

22. Turrell G, Kavanagh AM, Draper G, Subramanian SV. Do places affect the probability of death in Australia? A multilevel study of area-leve disadvantage, individual-level socioeconomic position and all-cause mortality, 1998-2000. J Epidemiol Community Health. 2007;61:13-9.

23. Suzuki E, Kashima S, Kawachi I, Subramanian SV. Social and geographic inequalities in premature adult mortality in Japan: a multilevel observational study from 1970 to 2005. BMJ Open. 2012;2, e000425.

24. Wilkinson RG, Pickett KE. Income inequality and socioeconomic gradients in mortality. Am J Public Health. 2008:98:699-704.

25. Borrell C, Pasarín MI. Inequalities in health and urban areas. Gac Sanit. 2004:18:1-4.

26. Mackenbach JP, Bakker MJ, European Network on Interventions and Policies to Reduce Inequalities in Health. Tackling socioeconomic inequalities in health: analysis of European experiences. Lancet. 2003;362:1409-14.

27. Stafford M, Martikainen P, Lahelma E, Marmot M. Neighbourhoods and self rated health: a comparison of public sector employees in London and Helsinki. J Epidemiol Community Health. 2004;58:772-8.

28. van Lenthe FJ, Borrell LN, Costa G, Diez-Roux AV, Kauppinen TM, Marinacci C, et al. Neighbourhood unemployment and all cause mortality: a comparison of six countries. J Epidemiol Community Health. 2005:59:231-7.

29. WHO/UN-HABITAT. Hidden cities: unmasking and overcoming health inequities in urban settings. Geneva: World Health Organization; 2010.

30. Rosicova K, Madarasova Geckova A, van Dijk JP, Rosic M, Zezula I, Groothoff JW. Socioeconomic indicators and ethnicity as determinants of regional mortality rates in Slovakia. Int J Public Health. 2009;54:274-83.
31. Bopp M, Minder CE. Mortality by education in German speaking Switzerland, 1990-1997: results from the Swiss National Cohort. Int J Epidemiol. 2003;32:346-54.

32. Lopez R. Income inequality and self-rated health in US metropolitan areas: a multi-level analysis. Soc Sci Med. 2004;59:2409-19.

33. Muller A. Education, income, inequality, and mortality: a multiple regression analysis. BMC Public Health. 2002;324:1-4.

34. Von dem Knesebeck O, Verde PE, Dragano N. Education and health in 22 European countries. Soc Sci Med. 2006;63:1344-51.

35. Behanova M, Nagyova I, Katreniakova Z, van Ameijden EJC, van Dijk JP, Reijneveld SA. The effect of urban-area unemployment on the mental health of citizens differs between Slovak and Dutch cities. Health Place. 2013;24:210-5

36. Behanova M, Nagyova I, Katreniakova Z, van Ameijden EJC, van Dijk JP, Reijneveld SA. Health-risk behaviours in deprived urban neighbourhoods: a comparison between Slovak and Dutch cities. Int J Public Health. 2014:59:405-14.

37. Mackenbach JP. Health inequalities: Europe in profile. Rotterdam: University Medical Centre, Department of Public Health; 2006.

38. Zatonski W, Manczuk M, Sulkowska U. Closing the health gap in European Union. Warsaw: Cancer Epidemiology and Prevention Division, the Maria Sklodowska-Curie Memorial Cancer Center and Institute of Oncology; 2008.

39. EU-MIDIS, European Union Minorities and Discrimination Survey. Main Results Report. 2009. European Union Agency for Fundamental Rights.

40. Vasecka M, Dzambazovic R. Socialno-ekonomicka situacia Romov na Slovensku ako potencionalnych migrantov a ziadatelov o azyl v krajinach EU. Socialna a ekonomicka situacia potencionalnych ziadatelov o azyl zo Slovenskej Republiky. International Organization for Migration (IOM); 2000. p. 17-62.

41. Filadelfiová J, Gerbery D, Škobla D. Správa o životných podmienkach rómskych domácností na Slovensku (Report on the Living Conditions of Roma in Slovakia). Bratislava: UNDP, Regional Bureau for Europe and the CIS; 2006.

42. Statistical Office of the Slovak Republic. Population by education from Population and Housing Census. Bratislava: Statistical Office of the Slovak Republic; 2002.

43. Statistical Office of the Slovak Republic. Monthly Statistics of unemployment. Bratislava: Centre of Labour, Social Affairs and Family of the Slovak Republic (UPSVAR); 2009

44. The Regional Statistical Yearbook of Slovakia 2006. Bratislava: Statistical Office of the Slovak Republic; 2007.

45. Statistical Office of the Slovak Republic. Population by nationality from Population and Housing Census. Bratislava: Statistical Office of the Slovak Republic; 2011.

46. Langford IH, Day RJ. Poisson regression. In: Leyland AH, Goldstein H, editors. Multilevel modelling of health statistics. Chichester: Wiley; 2001. p. 45-57.

47. Korec P. Regionálny rozvoj Slovenska v rokoch 1989-2004 (Regional development of the Slovak Republic in years 1989-2004). Geografika: Bratislava; 2005

48. Vaňo, B, Haviarová E, 2003. Demografické trendy rómskej populácie (Demographic trends of the Roma population). In: Vašečka, M., ed., Čačipen Pal o Roma. Súhrnná správa o Rómoch na Slovensku (A Global Report on Roma in Slovakia), IVO (Institute for Public Affairs), Bratislava.

49. Borrell C, Marí-Dell Olmo M, Serral G, Martínez-Beneito M, Gotsens M. Inequalities in mortality in small areas of eleven Spanish cities (the multicenter MEDEA project). Health Place. 2010;16:703-11.

50. Diez-Roux AV, Green Franklin T, Alazraqui M, Spinelli H. Intraurban variations in adult mortality in a large Latin American city. J Urban Health. 2007;84:319-33.

51. Rosicova K, Madarasova Geckova A, van Dijk J, Kollarova J, Rosic M, Groothoff JW. Regional socioeconomic indicators and ethnicity as predictors of regional infant mortality rate in Slovakia. Int J Public Health. 2011;56:523-31.

52. Rosicova K, Madarasova Geckova A, Rosic M, Speybroeck N, Groothoff JW, van Dijk J. Socioeconomic factors, ethnicity and alcohol-related mortality in regions in Slovakia. What might a tree analysis add to our understanding? Health Place. 2011;17:701-9.

53. van Hooijdonk C, Droomers M, Deerenberg IM, Mackenbach JP, Kunst AE. Higher mortality in urban neighbourhoods in The Netherlands: who is at risk? J Epidemiol Community Health. 2008;62:499-505.

54. Ginter E, Krajcovicova-Kudlackova M, Kacala O, Kovacic V, Valachovicova M. Health status of Romanies (Gypsies) in the Slovak Republic and in the neighbouring countries. Bratisl Lek Listy. 2001;102:479-84.

55. Hajioff S, McKee M. The health of the Roma people: a review of the published literature. J Epidemiol Community Health. 2000;54:864-9. 
56. Koupilova I, Epstein H, Holcik J, Hajioff S, McKee M. Health needs of the Roma population in the Czech and Slovak Republics. Soc Sci Med. 2001;53:1191-204.

57. Kosa Z, Szeles G, Kardos L, Kosa K, Nemeth R, Orszagh S, et al. A comparative health survey of the inhabitants of Roma settlements in Hungary. Am J Public Health. 2007;97:853-9.

58. Kolarcik P, Madarasova Geckova A, Orosova O, van Dijk JP, Reijneveld SA. To what extent does socioeconomic status explain differences in health between Roma and non-Roma adolescents in Slovakia? Soc Sci Med. 2009;68:1279-84

59. Vokó Z, Csépe P, Németh R, Kósa K, Széles G, Ádány R. Does socioeconomic status fully mediate the effect of ethnicity on the health of Roma people in Hungary? J Epidemiol Community Health. 2009;63:455-60.

60. Kolarcik P. Self-reported health and health risky behaviour of Roma adolescents in Slovakia: A comparison with non-Roma (PhD thesis). Rijksuniversiteit Groningen; 2012.

61. European Union Agency for Fundamental Rights, UNDP. The situation of Roma in 11 EU Member States: Survey results at a glance. Luxembourg: Publications Office of the European Union; 2012.

62. Population and Housing Census 2001. Selected indicators - Methodological notes. Statistical Office of the Slovak Republic; 2008. http://

slovak.statistics.sk/wps/portal/ext/themes/demography/census/metadata/lut/ p/b1/jdBLDolwEAbgs3gBOuVR2mVBKZiKhQJqNwaNMSSCLozG24vGhSaZjfJ909mBhk0R6arT822Pjb7rt7dekOWIVQ0CDAHGk8wJJFUIRoVOA-gB4tnIPy iB2mqy4pmTsbs_Kh4LHrSwAqhQcJj8ucZY4D3PkvDx-Kw6_8GJIm1Vrnd WuB5bFA59g5gG4BHtohszrgDf33UGklc2ZK8JhPoOgKUKbaklsEOOHAPw A315wB19uTON9u0F606FDW5bzi04atR1cAYJFsiQ!/dl4/d5/L2dJQSEvUU t3QS80SmtFL102X1ZMUDhCQjFBMEc3VDEwSU5OU.

63. Commission on Social Determinants of Health. Closing the gap in a generation: health equity through action on the social determinants of health. Final Report. Geneva: World Health Organization; 2008. Accessed 6 Aug 2014

\section{Submit your next manuscript to BioMed Central and take full advantage of:}

- Convenient online submission

- Thorough peer review

- No space constraints or color figure charges

- Immediate publication on acceptance

- Inclusion in PubMed, CAS, Scopus and Google Scholar

- Research which is freely available for redistribution 